\begin{tabular}{cc}
\hline JPPIPA, Vol.2 No.1 2017 \\
Jurnal Penelitian Pendidikan IPA
\end{tabular}

\title{
POTENSI SENSOR SERAT OPTIK DETEKSI KONSENTRASI KOLESTEROL SEBAGAI MEDIA PEMBELAJARAN GELOMBANG DAN OPTIK
}

\section{Oleh:}

Moh. Budiyanto ${ }^{1}$, Suhariningsih ${ }^{2}$, Moh. Yasin ${ }^{3}$

${ }^{1}$ Jurusan IPA, Fakultas MIPA, Universitas Negeri Surabaya, Surabaya 60231, Indonesia.

${ }^{2,3}$ Jurusan Fisika, Fakultas Sains and Teknologi, Universitas Airlangga, Surabaya 60115, Indonesia.

\begin{abstract}
Abstrak
Penggunaan media pembelajaran sangat dibutuhkan salah satu mata kuliah gelombang dan optik. Salah satu solusi penggunaan media pembelajaran pada perkuliahan gelombang dan optik dengan menggunakan sensor serat optik untuk deteksi konsentrasi kolesterol. Penelitian ini bertujuan untuk mendeteksi konsentrasi kolesterol dengan prinsip perambatan sinar laser yang dipandu serat optik coupler sebagai profil berbasis intensitas melalui medium larutan kolesterol dengan konsentrasi yang bervariasi. Adapun variasi konsentrasi larutan kolesterol adalah 0 ppm, 50 ppm, 100 ppm, 150 ppm, 200 ppm, 250 ppm, dan 300 ppm. Mekanisme kerja deteksi konsentrasi kolesterol adalah perambatan sinar laser He-Ne panjang gelombang 632,5 nm melalui serat optik coupler pada larutan kolesterol dan dipantulkan kembali oleh cermin datar kemudian sinar pantul dipandu melalui serat optik coupler sehingga terdeteksi oleh detektor silikon SL-818 yang berupa tegangan output. Hasil pendeteksian menunjukkan bahwa tegangan output maksimum menunjukkan penurunan secara linier terhadap peningkatan konsentrasi larutan kolesterol dengan sensitivitas 0,0016 mV/ppm dan linieritas lebih dari $96 \%$. Hasil penelitian ini menunjukkan parameter dan kinerja sensor yang akurat sehingga memiliki potensi sebagai media perkuliahan gelombang dan optik.
\end{abstract}

Kata Kunci : media pembelajaran, sensor serat optik, dan larutan kolesterol.

\begin{abstract}
The use of instructional media is needed one of the courses of wave and optics. One solution is the use of learning media on wave and optical lectures by using fiber optic sensors for cholesterol concentration detection. This study aimed to detect cholesterol concentration with laser propagation principle guided by fiber optic coupler as an intensity-based profile through medium of cholesterol solution with varying concentration. The variation concentration of cholesterol solution is 0 ppm, 50 ppm, $100 \mathrm{ppm}, 150 \mathrm{ppm}, 200 \mathrm{ppm}, 250 \mathrm{ppm}$, and $300 \mathrm{ppm}$. The work mechanism of cholesterol concentration detection is laser propagation of He-Ne wavelength $632.5 \mathrm{~nm}$ through fiber optic coupler in cholesterol solution and reflected back by flat mirror then ray reflected through fiber optic coupler so detected by $S L-818$ silicon detector in the form of voltage Output. The detection results showed that the maximum output voltage showed a linear decrease in the concentration of cholesterol solution with a sensitivity of $0.0016 \mathrm{mV} / \mathrm{ppm}$ and linearity of more than 96\%. The results of this study indicate the parameters and performance of sensors that have accurate potential as a medium for learning wave and optics.
\end{abstract}

Keywords: learning media, fiber optic sensor, and cholesterol lsolution.

(C) 2017 Universitas Negeri Surabaya

Alamat Korespondensi:

Jurusan IPA, Fakultas MIPA, Universitas

p-ISSN: 2527-7537

Negeri Surabaya, Surabaya 60231, Indonesia

e-ISSN: 2549-2209

Email: mohammadbudiyanto@unesa.ac.id 


\section{PENDAHULUAN}

Pembelajaran Penyelenggaraan perkuliahan berpegang pada prinsip efisiensi dan efektivitas yakni pemanfaatan waktu yang terbatas secara optimal untuk mencapai tujuan. Karena itu, tiap metode perkuliahan yang dipilih, diorientasikan pada tujuan prinsip umum yang digunakan dalam proses belajar mengajar dengan cara belajar konstruktivis. Proses belajar mengajar dituntut adanya interaksi antara pendidik dan peserta didik. Interaksi dalam proses belajar mengajar antara dosen dengan mahasiswa dimana dosen sebagai fasilitator dengan mahasiswa dituntut untuk lebih aktif dalam pembelajaran dan didukung adanya media pembelajaran (Budiyanto, 2011).

Salah satu sumber belajar yang dapat memperkaya wawasan anak didik adalah media pembelajaran. Peranan media tidak akan terlihat bila penggunaanya tidak sejalan dengan isi dan tujuan pembelajaran yang telah dirumuskan. Karena itu, tujuan pembelajaran harus dijadikan sebagai acuan dalam menggunakan media pembelajaran terutama tujuan pembelajaran yang membutuhkan percobaan seperti sifat perambatan dan pemantulan gelombang.

Media pembelajaran dalam pembelajaran sains merupakan sarana yang berfungsi menyampaikan informasi belajar dapat memberikan kontribusi positif dalam proses pembelajaran yang interaktif, efektif dan menumbuhkan rasa ingin tahu mahasiswa terhadap konsep-konsep sains yang ditunjukkan oleh media tersebut.

Penggunaan media pembelajaran sangat dibutuhkan salah satu mata kuliah gelombang dan optik. Dimana deskripsi mata kuliah ini salah satunya mencakup tentang konsep getaran, gejala gelombang, kecepatan gelombang dalam berbagai medium, gelombang elektromagnetik, pantulan dan pembiasan cahaya, alat optik, polarisasi, interferensi, difraksi dan modulasi gelombang dan integrasinya dengan ilmu sains lainya (biologi dan kimia). Salah satu tujuan matakuliah gelombang dan optik adalah mampu menerapkan konsep sifat perambatan, serapan, dan pemantulan gelombang maka alaternatif pemecahan masalahnya penggunaan sensor serat optik untuk menentukan konsentrasi kolesterol berpotensi penggunaan media yang sesuai dengan pencapaian tujuan pembelajaran.

Dari uraian tersebut peneliti ingin memberikan salah satu solusi penggunaan media pembelajaran pada perkuliahan gelombang dan optik dengan menggunakan sensor serat optik untuk deteksi konsentrasi kolesterol. Penggunaan media sensor merupakan penerapan praktis konsep rambatan, serapan, dan pemantulan gelombang untuk memecahkan masalah dalam hal ini penentuan konsentrasi kolsterol secara cepat dan akurat. Dengan menentukan parameter-parameter yang dihasilkan oleh sensor serat optik yang akurat dan mekanisme penggunaan media ini mudah diset dengan memandu gelombang melalui serat optik untuk menuju larutan atau bahan yang kemudian dipantulkan kembali melalui serat optik untuk mendeteksi tegangan output, maka dapat dikatakan penggunaan sensor ini mudah dan sederhana serta berpotensi sebagai media pembelajaran gelombang dan optik.

Kolesterol merupakan senyawa yang memiliki inti empat cincin siklopentano - fenantren. Termasuk lemak dengan daya larut yang sangat kecil dalam air. Kadarnya dalam plasma darah 150$200 \mathrm{mg} / \mathrm{ml}$, sekitar 2x kadar glukosa darah. Dalam plasma darah $30 \%$ berikatan dengan lipoprotein yang mampu menambah daya larutnya dalam darah. Sebanyak 70\% lagi kolesterol darah berada berupa kolesterol ester. Kolesterol tidak larut dalam air tetapi dapat diekstraksi dari jaringan dengan kloroform, eter, benzena dan alkohol panas. Kolesterol di dalam darah beredar tidak dalam keadaan bebas, akan tetapi berada dalam partikelpartikel lipoprotein. Lipoprotein merupakan senyawa kompleks antara lemak dan protein. Dalam serum darah lipoprotein terdiri atas 4 jenis, yaitu kilomikron, very low density lipoprotein (VLDL), low density lipoprotein (LDL), dan high density lipoprotein (HDL). Kilomikron mengandung $96 \%$ trigliserida, $1,7 \%$ protein, $1,75 \%$ kolesterol, dan $0,6 \%$ fosfolipida. Kilomikron berfungsi sebagai pengangkut lemak dari usus ke tempat-tempat yang membutuhkan. VLDL mengandung $60 \%$ trigliserida, $15 \%$ kolesterol, $10 \%$ protein, dan $15 \%$ fosfolipida. VLDL berfungsi sebagai pengangkut trigliserida endogen dari tempat-tempat pembentukannya ke tempat yang membutuhkan. LDL mengandung $10 \%$ trigliserida; $45 \%$ kolesterol, $25 \%$ protein, dan $20 \%$ fosfolipida. LDL berfungsi mengangkut kolesterol dari sel yang satu ke sel lainnya dimana kolesterol tersebut diperlukan untuk pembentukan hormon sterol dan steroid. HDL mengandung 3\% trigliserida, $18 \%$ kolesterol, $50 \%$ protein, dan $30 \%$ fosfolipida. Kolesterol tidak larut dalam air tetapi dapat diekstraksi dari jaringan dengan kloroform, eter, benzena dan alkohol panas. Kolesterol termasuk senyawa steroida dengan rumus $\mathrm{C}_{27} \mathrm{H}_{45} \mathrm{OH}$. Kolesterol adalah salah satu sterol yang penting dan terdapat banyak di alam. Dari rumus kolesterol dapat di lihat bahwa gugus hidroksil yang terdapat pada atom $\mathrm{C}$ nomor 3 mempunyai posisi beta oleh karena dihubungkan oleh garis penuh.

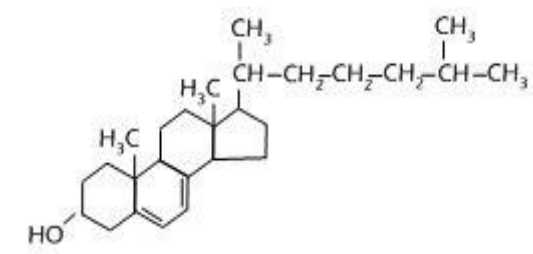

Gambar 1. Senyawa kolesterol 
Adapun deteksi konsentrasi kolesterol sudah banyak dilakukan peneliti seperti sensor elektrokimia sensitif dan selektif menggunakan perak nanopartikel dimodifikasi elektroda karbon kaca untuk penentuan kolesterol dalam serum bovine (Siriwan et al, 2015). Sensor elektrokimia berdasarkan cetak film molekuler pada nanopartikel karbon yang dimodifikasi elektroda untuk penentuan kolesterol (Jian et al, 2015). Lapisan nanotube karbon dan emas nanopartikel berbasis biosensor bienzyme untuk deteksi kolesterol (Xiaojun et al, 2013). Deteksi kolesterol dengan amperometri menggunakan elektrokimia metode oksidasi (Chiang et al, 2011). elektrokimia dan optik polimer dengan menggunakan biosensor untuk mendeteksi kolesterol (Saniye et al, 2011). Kelemahan dari sensor-sensor tersebut optimasi kinerja sensor seperti kepekaan, jangkauan linear dan batas deteksi masih kurang maksimal.

Cara lain untuk menentukan konsentrasi kolesterol ini dapat ditentukan melalui karakter sinar laser terhadap bahan melalui sensor serat optik. Metode sensor serat optik lebih simpel dan murah untuk digunakan menentukan konsentrasi suatu bahan. Salah satu contoh sensor fiber optik untuk menentukan kadar garam pada suatu bahan merupakan rancangan instrumen yang simpel, harga murah, dan hasil pengukuran sensitivitas tinggi (M.Yasin, 2013). Berdasarkan uraian ini akan dikembangkan penelitian sensor serat optik sebagai Model instrumen menentukan konsentrasi kolesterol dengan menggunakan sensor serat optik coupler.

\section{METODE}

Metode penelitian menentukan konsentrasi kolesterol ditentukan berdasarkan karakter sinar laser terhadap bahan melalui sensor serat optik dengan menggunakan modulasi intensitas sinar Laser. Berkas cahaya yang masuk ke serat optik penerima dan diproses oleh detektor optik menjadi sinyal listrik yang akan ditampilkan di komputer. Hasil eksperimen akan diperoleh hubungan linieritas antara tegangan puncak luaran sensor sebagai fungsi variasi konsentrasi kolesterol dan akan diukur paramater dan kinerja sensor meliputi sensitivitas, jangkauan linier, dan linieritas.

Perangkat penelitian terdiri dari laser $\mathrm{He}-\mathrm{Ne}$ (Thorlabs, $632.5 \mathrm{~nm}, 5 \mathrm{~mW}$ ), Serat optik coupler, detektor optik 818-SL (Newport), chopper dan chopper controler (SR540, Stanford Research System, Inc.), Lock-in amplifier (SR510, Stanford Research System, Inc.), cermin panjang gelombang cahaya tampak (5101-Vis, New Focus), mikrometer posisi (Newport), PC, serta perangkat pendukung lainnya.
Langkah awal adalah melakukan karakterisasi sensor pergeseran untuk mengetahui pergeseran kanal sensing fiber coupler terhadap cermin datar. Selanjutnya adalah melakukan deteksi konsentrasi kolesterol dengan membuat set-up seperti gambar berikut :

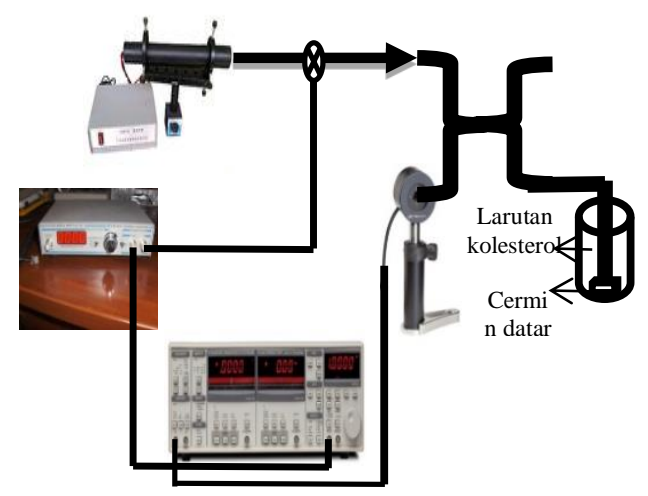

Gambar 2. Rancangan Sensor serat optik menentukan konsentrasi kolesterol dengan menggunakan fiber Coupler

Pendeteksian dimulai saat fiber coupler yang ditempatkan berimpit dengan cermin yakni pada pergeseran $\mathrm{z}=0$. Fiber coupler ditempatkan pada mikrometer posisi digeser tiap $50 \mu \mathrm{m}$. Pada tiap posisi pergeseran tegangan keluaran detektor diukur sehingga diperoleh data berupa tegangan luaran detektor sebagai fungsi pergeseran fiber coupler. Pendeteksian dilakukan terhadap beberapa variasi konsentrasi antara lain 0 ppm, 50 ppm, 100 ppm, 150 ppm, 200 ppm, 250 ppm, 300 ppm.

\section{HASIL DAN PEMBAHASAN}

Gambar 3. menunjukkan grafik tegangan keluaran detektor sebagai fungsi pergeseran fiber coupler untuk masing-masing konsentrasi mulai 0 ppm sampai 300 ppm. Gambar tersebut menunjukkan adanya hubungan perubahan variasi konsentrasi kolesterol terhadap tegangan keluaran maksimum pada masing-masing konsentrasi. Semakin tinggi konsentrasi kolesterol semakin rendah tegangan keluaran detektor yang terukur.

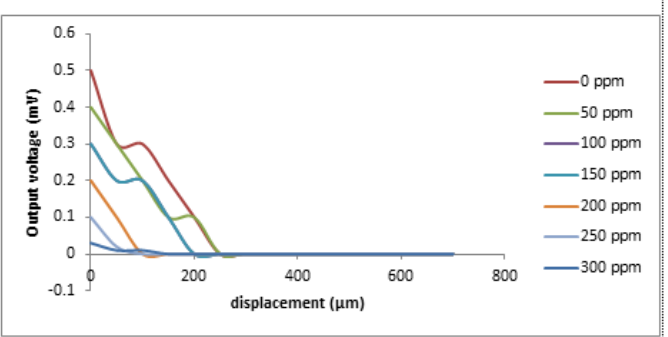

Gambar 3. Grafik tegangan keluaran detektor sebagai fungsi pergeseran fiber coupler 
Data pendeteksian tegangan keluaran detektor dimulai saat fiber coupler yang ditempatkan berimpit dengan cermin yakni pada pergeseran $\mathrm{z}=$ 0 . Fiber bundle ditempatkan pada mikrometer posisi digeser tiap $50 \mu \mathrm{m}$. Pada tiap posisi pergeseran tegangan keluaran detektor diukur sehingga diperoleh data berupa tegangan luaran detektor sebagai fungsi pergeseran fiber coupler, sehingga memperoleh tegangan keluaran maksimum dari masing-masing variasi konsentrasi kolesterol. Adapun nilai tegangan luaran maksimum dari variasi konsentrasi kolesterol seperti pada tabel 1 .

Tabel 1. Nilai Tegangan Luaran Maksimum Dari Variasi Konsentrasi Kolesterol

\begin{tabular}{ccc}
\hline Data & Konsentrasi $(\mathbf{p p m})$ & Tegangan output $(\mathbf{m V})$ \\
\hline 1 & 0 & 0.5 \\
2 & 50 & 0.4 \\
3 & 100 & 0.3 \\
4 & 150 & 0.2 \\
5 & 200 & 0.1 \\
6 & 250 & 0.05 \\
7 & 300 & 0.03 \\
\hline
\end{tabular}

Gambar 4. menunjukkan bahwa tegangan output maksimum menunjukkan penurunan secara linier terhadap peningkatan konsentrasi larutan kolesterol dengan sensitivitas $0,0016 \mathrm{mV} / \mathrm{ppm}$ dan linieritas $96,96 \%$.

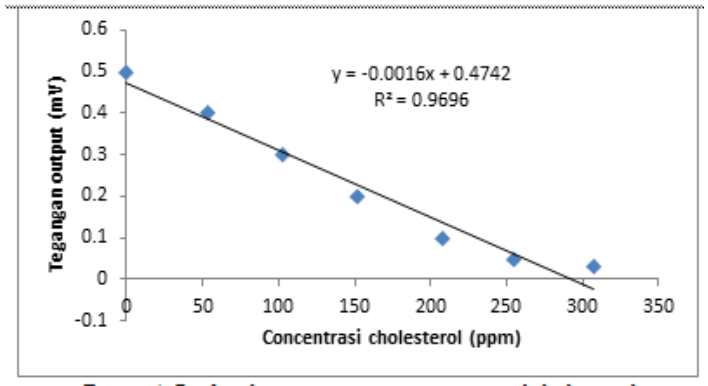

Gambar 4. Tegangan puncak terhadap variasi konsentrasi kolesterol

\section{PENUTUP}

Sensor serat optik berdasarkan modulasi intensitas dapat mendeteksi konsentrasi kolesterol. Hasil analisis pendeteksian menunjukkan bahwa tegangan output maksimum menunjukkan penurunan secara linier terhadap peningkatan konsentrasi larutan kolesterol dengan sensitivitas 0,0016 $\mathrm{mV} / \mathrm{ppm}$ dan linieritas 96,96\%. Dengan parameter hasil eksperimen dan kemudahan rancangan sensor ini diset maka sensor serat optik dapat berpotensi sebagai media pembelajaran untuk mendukung pembelajaran mata kuliah gelombang dan optik.

\section{DAFTAR PUSTAKA}

Asieh Ahmadalinezhad, Aicheng Chen. 2011. High-performance electrochemical biosensor for the detection of total cholesterol, Biosensors and Bioelectronics 26, 4508 - 4513.

Budiyanto.M. 2011. Peningkatan Hasil Belajar Mahasiswa Sains Pada Pembelajaran Interaksi Antar Faktor Fisik (IAFF) Dengan Media Pembelajaran Motor Listrik. Laporan PTK Lembaga Penelitian Unesa.

Cox B. 2013. Introduction to Laser-Tissue Interactions, Optics In Medicine

Csele, M. 2004. Fundamental of Light Sourcesand Laser. John Wiley and Sons

Faria J.B. 1998. A theoretical analysis of the bifurcated fiber bundle displacement sensor. IEEE Trans on Inst and Meas., vol. 47, pp. 742-747.

Griffith.DJ. $1999 . \quad$ Introduction to Elektrodynamics. New Jersey. Prentice Hall.

Hida N., N. Bidin, M. Abdullah, M. Yasin. 2013. Fiber Optic Displacement Sensor for Honey Purity Detection in Distilled Water. Optoelectronics and Advanced Materials Vol. 7, No. 7 - 8. p. 565 - 568.

Jatmiko B, Wahono W., Martini, Budiyanto M. 2015. Buku Prototipe Kurikulum Pendidikan Sains Berorientasi KKNI. Jaudar Press.

Jian Ji, Zhihui Zhou, Xiaolian Zhao, Jiadi Sun, Xiulan Sun. 2015. Electrochemical sensor based on molecularly imprintedfilm at $\mathrm{Au}$ nanoparticles-carbon nanotubes modified electrode for determination of cholesterol. Biosensors and Bioelectronics 66, 590-595.

Niemz, M.H. 2007. Laser Tissue Interaction, Fundmental and Aplication. Third Enlarge Edition, Springer

Perez Miguel A., Gonzalez Olaya, Arias Jose R. 2013. Optical Fiber Sensors for Chemical 
and Biological Measurements. Licensee InTech.

Prasad, P.N. 2003. Introduction to Biophotonics, Wiley Interscience, John Wiley Publication

Rahman H. A., S. W. Harun, M. Yasin, H. Ahmad. 2012. Fiber Optic Salinity Sensor Using Beam-Through Technique. Optik xxx.

Rahman H. A., S. W. Harun, M. Yasin, H. Ahmad. 2012. Fiber Optic Salinity Sensor Using Fiber Optic Displacement Measurement with Flat and Concave Mirror. IEEE Journal of Selected Topics in Quantum Electronics, Vol. 18, No. 5, pp. 1529 - 1533.

Rahman H. A. , S. W. Harun, Saidin N., M. Yasin, H. Ahmad. 2012. Fiber Optic Displacement Sensor for Temperature Measurement. IEEE Sensors Journal Vol. 12, No. 5, pp. $1361-1364$.

Saniye Soylemez, Yesemin A.U., Cevher Gundo H., Yavuz Ergun, Levent T. 2015. Electrochemical and optical properties of a conducting polymer and its use in a novel biosensor for the detection of cholesterol. Sensors and Actuators B 212, 425-433.

Sastikumar D., G. Gobi, B. Renganathan. 2010. Determination of The Thicness of $\mathrm{A}$ Transparent Plate Using A Reflective Fiber Optic Displacement Sensor. Optics \& Laser Technology, 42, 911 - 917

Siriwan Nantaphola, Orawon Chailapakul, Weena S. 2015. Sensitive and selective electrochemical sensor using silver nanoparticles modified glassy carbon electrode for determination of cholesterol in bovine serum, Sensors and Actuators B 207, 193-198.

Swatland H. J. 2001. Effect Of Connective Tissue On The Shape Of Reflectance Spectra Obtained With A Fibre-Optic Fat-Depth Probe In Beef. Meat Science, 57, 209 - 213.

Xiaojun Cai, Xia Gaoa L.W., Xianfu Lin. 2013. A layer-by-layer assembled and carbon nanotubes/gold nanoparticles-based bienzyme biosensor for cholesterol detection, Sensors and Actuators B 181, 575- 583

Yasin M., H. Ahmad, K. Thambiratnam, A. A. Jasim, S. W. Phang, S. W. Harun. 2013. Design of Multimode Tapered Fibre Sensor for Glucose Detection, Optoelectronics and Advanced Materials Vol. 7, No. 5 - 6. p. 371 - 376.

Yasin M., Harun S.W., Kusminarto, Karyono, Ahmad H. 2007. Construction of fiber optic sensor for micro-displacement measurement based on refelctive intensity modulation techniuque., $2^{\text {nd }}$ Jogja International Physics Conference, 6-8 September, Gadjah Mada University, Yogayakarta. 